\title{
Pulmonary hypertension syndrome in broiler chickens: a review
}

\author{
Avishek Biswas \\ Avian Nutrition and Feed Technology Division, ICAR-Central Avian Research Institute, Izatnagar, India
}

\section{BISWAS, A.: Pulmonary hypertension syndrome in broiler chickens: a review. Vet. arhiv 89, 723-734, 2019.}

\section{ABSTRACT}

Accumulation of fluid in the abdominal cavity, cardiac anomalies, including an enlargement, soft heart as well as right ventricular hypertrophy, are collectively known as ascites syndrome of broilers. Ascites was first noticed as a problem in commercial poultry farms located at high altitude. There are four general factors in ascites fluid buildup, that is: vascular damage that allows capillaries to leak; blockage of the lymphatic system that prevents drainage; decreased plasma oncotic pressure, and increased vascular hydraulic pressure, which can be caused by several types of pathologies, including hepatic, cardiac or right atrioventricular and pulmonary hypertension. Most cases of these metabolic diseases seen in commercial poultry farm are due to pulmonary hypertension. Pulmonary hypertension originates from various causes such as: environmental causes i.e., altitude, cold stress and incubator environment; management causes i.e., feed management, the form of feed, dietary content etc.; developmental causes i.e. growth rate, oxygen requirement, organ size and capacity, hematological parameters. All these factors cause ascites syndrome by inducing hypoxia in commercial birds. Genetic selection has great potential to influence and end ascites syndrome. In the past, genetic selection tools were used for rapid growth, high meat yield and good feed conversion. However, genetic selection may have aggravated the ascites problem and now it is the best solution for eliminating this metabolic disorder. With the advent of molecular genetics research and the development of genetic markers, it is possible to determine the exact genetic basis of ascites; genetic markers may be used to eliminate ascites syndrome from modern commercial broilers.

Key words: metabolic disorder; pulmonary hypertension; ascites; genetic selection; broiler

\section{Introduction}

Ascites is a condition in which excess amounts of ascitic fluids, i.e. a combination of lymph and blood plasma, has leaked from the liver, accumulating in the body cavity. Other symptoms of this disease include enlarged flaccid heart and variable liver changes. The enlarged, flaccid heart is due to the dilation and hypertrophy of the right ventricle

\footnotetext{
${ }^{*}$ Corresponding author:

Avishek Biswas, Senior Scientist, Avian Nutrition and Feed Technology Division, ICAR-Central Avian Research Institute, Izatnagar-243122 (U.P.), Phone: +91 5812303 223; E-mail: drbiswas007@gmail.com
} 
and the right atrioventricular valve (WIDEMAN et al., 2013). During ascites syndrome, hemoglobin, hematocrit values, and RBC counts all increase dramatically (CLOSTER et al., 2012) and there is lowered oxygen tension, reduced capillary blood flow, polycythemia and increased blood viscosity (WIDEMAN et al., 2009). Ascites syndrome has multifactoral etiology i.e. environmental conditions such as high altitude, temperature, lighting and ventilation; and nutritional factors such as feed content, and type of feed (JULIAN, 2007). The condition often leads to death in broiler chickens. In the last two decades, ascites has become a significant problem in broilers reared at low elevations. This increase coincides with ongoing genetic and nutritional improvements in the areas of growth rate and feed efficiency (BAGHBANZADEH and DECUYPERE, 2008). Selection for rapid growth and efficient feed conversion has resulted in a broiler with such a high rate of metabolism that its heart and lungs are barely capable of providing enough oxygen to sustain the body (ZOER et al., 2009). The high $\mathrm{O}_{2}$ demands of rapid growth increase the pulmonary arterial pressure and the workload of the heart. The broilers may not always be able to adapt to the increased $\mathrm{O}_{2}$ demands related to environmental stresses and are more susceptible to ascites syndrome (BALOG, 2003).

Mortality rates due to ascites condition vary from $5 \%$ in broiler flocks to $20 \%$ in heavier roaster flocks. There are several management techniques (feed restriction, intermittent lighting) used to combat ascites syndrome in broilers, which all involve reducing the rapid growth rate of the birds which is often not economically feasible for poultry farmers (BALOG et al., 2000).

The objective of the present review is to discuss the factors that influence the development of ascites syndrome, and to evaluate the technology for eliminating the ascites syndrome from commercial poultry production.

\section{Ascites syndrome development}

Physiological, environmental factors, management, anatomical and genetic factors either increase production or decrease the removal of peritoneal lymph in case of ascites syndrome.

Physiological causes. Ascites caused by vascular damage typically occurs when fluid and plasma proteins escape through the vascular endothelium, which may be caused by viral infections, bacterial infections and chemical toxins (WIDEMAN et al., 2013). Lymphatic obstruction can be secondary to right ventricular failure with valvular insufficiency, in which high venous pressure in the vena cava interferes with lymph return (ZHOU et al., 2008). Ascites-susceptible young birds have lower levels of plasma albumin and plasma protein as compared to young white leghorns (XIANG et al., 2004). The loss of high protein lymph from the liver could decrease plasma protein, or right ventricular hypertrophy causes the bird to stop eating, which naturally lowers plasma protein levels. 
This is the most common cause of ascites syndrome in broilers. The increased vascular pressure is classified in three categories. First, hepatic pathologies, such as hepatic fibrosis, can cause fluid to seep from the liver and accumulate in the abdominal cavity (ZOER et al., 2009). The second category of pathologies that cause increased hydraulic pressure are general cardiac pathologies. Viral infection, particularly adenovirus infection, has been reported to cause ascites and myocarditis (AREIZA-ROJAS et al., 2011; AUSTIN et al., 2010). The third category of pathologies is pulmonary hypertension, which increases vascular pressure and is the most common etiology associated with ascites syndrome in broilers.

Environmental causes. High altitude plays an important role in ascites development in broiler birds. At high altitude, mortality occurred due to right ventricular hypertrophy and failure, congested and edematous lungs, and the accumulation of fluid in the abdominal cavity (HASSANZADEH et al., 2002). High altitude (either natural or simulated) decreases the partial pressure of oxygen, whereas at sea level $\mathrm{O}_{2}$ makes up $20.9 \%$ of the atmospheric pressure. Every $500 \mathrm{~m}$ rise in elevation the atmospheric pressure loses approximately $1.0 \% \mathrm{O}_{2}$ (JULIAN, 2000). The ability of different species of birds to compensate for lowered atmospheric oxygen is highly variable. Some birds have been reported to maintain normal arterial oxygen levels at $2500 \mathrm{~m}$ above sea level (AHMED et al., 2013) whereas some broilers have low arterial blood oxygen at sea level (HASSANZADEH et al., 2002). The pulmonary blood vessels are constricted, and pulmonary vascular resistance increases, which causes right ventricular hypertrophy and eventually the ascites syndrome develops when birds are exposed to low atmospheric oxygen levels (WIDEMAN, 2000).

It has been recognized for several decades that there is a strong correlation between cold temperature and cardiac hypertrophy or ascites. Chickens have a very narrow thermo neutral zone and respond to cold stress by increasing their metabolism and oxygen requirements (IZADINIA et al., 2010). A drop in environmental temperature from 20 ${ }^{\circ} \mathrm{C}$ to $2{ }^{\circ} \mathrm{C}$ almost doubled the $\mathrm{O}_{2}$ requirements of white leghorn hens (BISWAS et al., 2010a). Increased metabolic oxygen requirements and pulmonary hypertension together increase ascites at cold temperatures. Ascites may be reduced under cold stress conditions through treatment with drugs such as 'meta-proterenol', which cause bronchial dilation and reduce pulmonary vascular resistant (IZADINIA et al., 2010). The duration of the cold stress is more critical than the minimum temperature reached. Exposure to suboptimal temperatures leads to ascites mortalities about two weeks later, and after three weeks of age, temperature stress becomes less critical (GROVES, 2002).

Several researchers investigated the evident effects of hypoxia on the development of ascites syndrome, where incubation may play an important role (DECUYPERE et al., 2000). A hypoxic challenge to embryos during incubation and hatching could compromise 
chick pulmonary vasculature development, which in turn would predispose the bird to ascites development. It is well-known that the pulmonary capillary system of chicken embryos develops rapidly during the last 3 days before hatching (BALOG et al., 2003). There is an overall reduction in growth rate and the underdevelopment of the pulmonary vasculature is possible if the embryos are subjected to hypoxia (AHMED et al., 2013). Reduction of egg shell conductance by covering portions of the shell with tape during incubation increased ascites susceptibility and could be used as a new model for the study of ascites syndrome (BALOG, 2003). Moreover, interfering with egg shell conductance during incubation resulted in an increase in the incidence of ascites. Embryos from an ascites resistant line had significantly shorter times to external piping and hatch than the times required for embryos from an ascites susceptible line of broilers (MALAN et al., 2003).

Management causes. Management of broiler flocks has a tremendous impact on the ascites incidence within the flocks. Good management and environmental practices that encourage high feed intake and rapid growth tend to exacerbate ascites. When ascites first appeared as a problem of commercial broiler production, researchers noted the increasing incidence of ascites syndrome in rapidly growing broilers (BISWAS et al., 2011). High feed intake results in an increase in the bird's oxygen requirement. The bird's food intake per unit metabolic body weight reaches its maximum at around 2-3 weeks of age and implies a marginal difference between the capacity to supply oxygen and the actual oxygen requirement to metabolize food (MALAN et al., 2003). It is believed that early feed restriction slows the bird's metabolism and reduces its oxygen requirements. With early feed restriction, the bird is prevented from experiencing the tremendous weight gains associated with the rapid deposition of muscle and fat (BISWAS et al., 2012). Additionally, a temporary growth restriction allows further development of the bird's cardio-pulmonary system, which is not impacted by the decreased growth rate.

Pelleted or crumbled feed is easier for birds to consume and is more digestible than mash feed. Pelleted feed has been associated with a significant increase in the incidence of ascites at low altitudes (BALOG et al., 2000), high altitudes (BISWAS et al., 2010b) and in cold temperatures (DEEB et al., 2002). The nutrient density of pelleted feed is higher compared to mash, and it increases the bird's metabolic rate and oxygen consumption. When pellets are made from grain, as opposed to ground, the incidence of ascites is also reduced, possibly due to decreased nutrient availability (MALAN et al., 2003). 
A. Biswas: Pulmonary hypertension syndrome in broiler chickens: a review

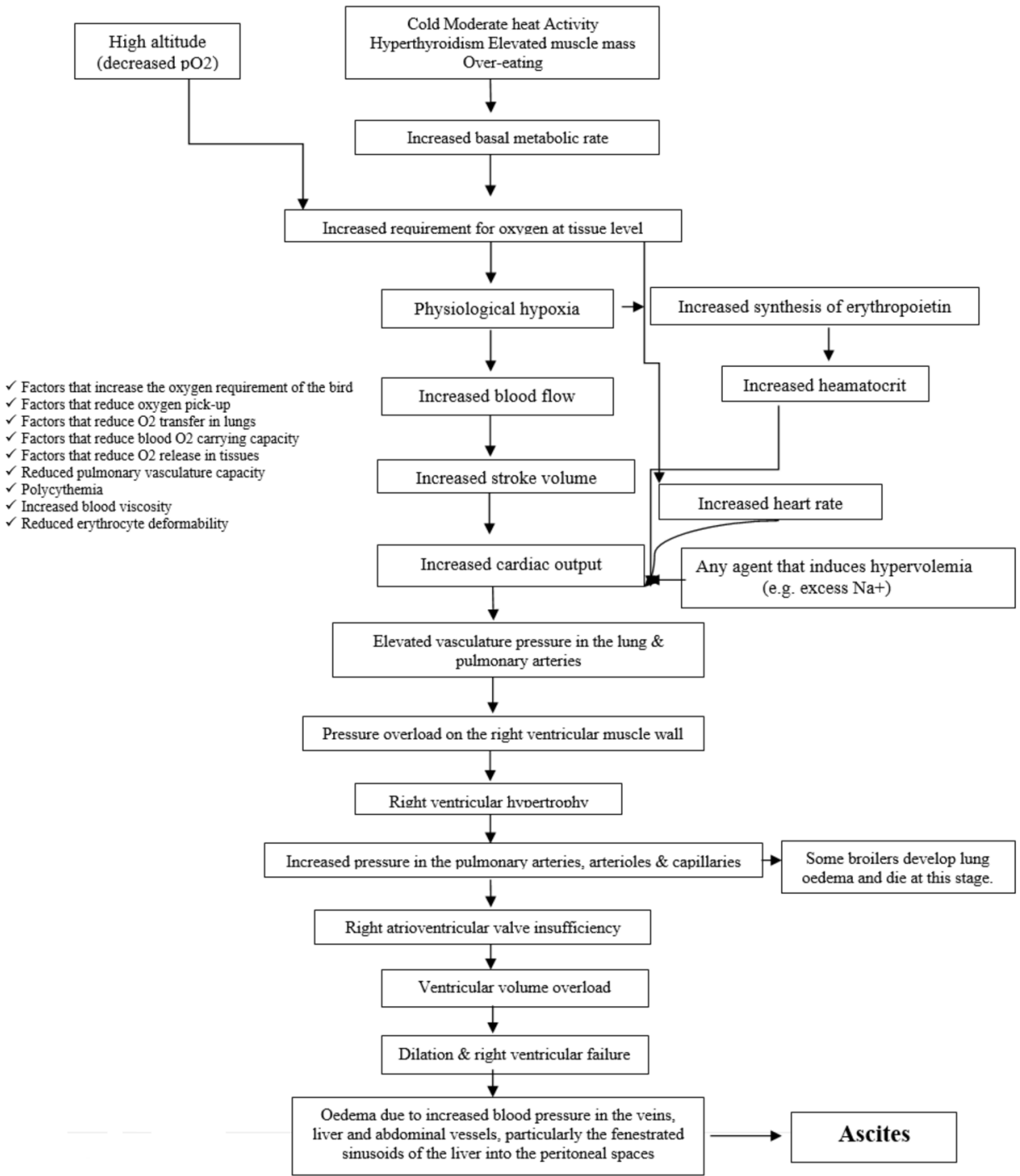

Fig. Physiological and pathophysiological factors affecting ascites syndrome (BAGHBANZADEH and DECUYPERE, 2008) 
It has been suggested that feeding high levels of protein and amino acids increases the incidence of ascites (MALAN et al., 2003). However, under normal experimental conditions other researchers have shown no ascites effect from dietary protein, lysine or energy- protein ratios (BALOG et al., 2000). Diets high in protein increased deamination of excess nitrogen as uric acid, and this process is energetically costly to the bird (JULIAN, 2000). Feeding of low protein, low energy diets for the first two weeks of the broiler rearing period may be a preventive measure for control of the ascites problem.

It is generally accepted that diets high in metabolizable energy increase the susceptibility of broilers to ascites, due to the resultant increase in growth rate and oxygen requirement (BEHROOJ et al., 2012). Reducing the energy level of the diet does not necessarily reduce ascites, as broilers on low energy diets tend to consume more feed and thus require more oxygen for digestion, which mimics the effects of high energy diets (JULIAN, 2000).

Increased dietary fat has been shown to increase ascites in broilers because fat increases the bird's oxygen requirement as it requires more oxygen for complete oxidation (AHMED et al., 2013). Diets with high fat and crude protein increased growth rates and ascites incidence, but if the metabolizable energy was held constant, increasing dietary fat levels by themselves did not increase the incidence of ascites (BEHROOJ et al., 2012). Growth rate and feed consumption can be maximized if broilers are reared on a near continuous lighting schedule. Decreased growth rates were observed for broilers with a step down lighting program. It was hypothesized that limiting the number of hours of light will slow growth slightly and will reduce activity that requires additional oxygen, and may actually improve feed efficiency (ZOER et al., 2009).

Poor ventilation could cause low environmental oxygen or high toxic fumes (carbon dioxide, carbon monoxide or ammonia) which may have detrimental effects on the respiratory or cardiovascular systems of birds, and promote ascites development (BALOG, 2003). Environmental dust could affect oxygen transfer in the lungs and increase ascites incidence (BEHROOJ et al., 2012)

Anatomical Causes. The architecture of the modern broiler consists of small stature, a large, heavy breast mass, the pressure from abdominal contents on air sacs and the small lung volume which may all be involved in the increased incidence of ascites syndrome (CLOSTER et al., 2012). The modern broiler has been selected for rapid growth and has experienced an improved growth rate of about $5 \%$ a year over the last 30 years (JULIAN, 2000). Breast muscle is primarily glycolytic white muscle, and is relatively independent of the bird's oxygen requirements. It has been speculated that selection for increased breast muscle yield will not result in a proportionate increase in heart, blood and lung mass, which leads to an exacerbation of the mismatch between the cardiopulmonary system and the muscle mass, resulting in an increased susceptibility to metabolic disease 
(DECUYPERE et al., 2005). Male and female broilers have different oxygen requirements, and males, with the greater requirement, are more prone to ascites incidence.

Hypoxia results in hypoxemia that causes an increase in red blood cell numbers through increased erythropoietin production (CLOSTER et al., 2012). Increased numbers of red blood cells (polycythemia) increased blood viscosity (AHMED et al., 2013; BISWAS et al., 2010b). Small rigid blood capillaries and large nucleated red blood cells, and the resultant polycythemia, are an important cause of increased resistance to blood flow in the lungs due to the anatomical arrangement of birds (JULIAN, 2000). Blood volume could also be a cause of ascites by causing volume overload and increased cardiac output, whereas decreasing blood volume may reduce ascites (WIDEMAN et al., 2013).

The avian left ventricle is thick-walled and the right ventricle is thin-walled. The atrioventricular valve is composed of muscle flap made up mainly of muscle fibers from the right ventricle wall. The anatomy of this valve makes birds very susceptible to valvular insufficiency (BALOG et al., 2003). The right ventricle responds to an increased workload whereby it becomes hypertrophic, and the valve hypertrophies along with the ventricle. This thickening of the valve interferes with its effectiveness and may lead to rapidly developing valvular failure and ascites. At the onset of ascites development, a decrease in heart rate has been reported in broilers. It was hypothesized that this reflects the longer cardiac cycle required by the dilated right ventricle to complete filling and then propel the requisite stroke volume through the relatively high pulmonary vascular resistance (WIDEMAN, 2001).

The role of pulmonary blood vessels in the development or progression of ascites syndrome has been studied especially. Birds with ascites, induced by either low ventilation or cold temperatures, exhibited hypertrophy of the medial layer of the arterials, which was probably a response to primary pulmonary hypertension (ZHOU et al., 2008).

Possible measures for controlling ascites (BISWAS et al., 2010a).

$\checkmark$ Lesser amount (0.15-0.3\%) of common salt in ration. Common salt potentiates ascites.

$\checkmark$ Ration should be alkalinized by adding $\mathrm{NaHCO}_{3}$.

$\checkmark$ Addition of selenium in diet helps prevent ascites.

$\checkmark$ If the drinking water (spring) is rich in salts then it should be stored overnight and the next day the upper scum layer should be removed before watering the birds.

$\checkmark$ Birds on high density nutrients / high energy, high C.P. \% are more prone to ascites.

$\checkmark \quad$ Feed a low protein / low energy diet during the first 14 days.

$\checkmark \quad$ Nitric Oxide helps in prevention of ascites.

$\checkmark \quad$ L-Arginine supplementation reduces the incidence of ascites by helping in the synthesis of endogenous nitric oxide which causes vasodilation.

$\checkmark$ Coenzyme $\mathrm{Q}_{10}$ has a beneficial effect in reducing ascites mortality @ $40 \mathrm{mg} / \mathrm{kg}$ of feed. 
A. Biswas: Pulmonary hypertension syndrome in broiler chickens: a review

$\checkmark \quad$ Frusemide (diuretic) at $0.001 \%, 0.005 \%$ and $0.01 \%$ significantly reduces ascites without lowering the final body weight.

$\checkmark \quad$ Increasing dietary bicarbonate and reducing dietary chloride has potential as a low cost and effective method to reduce ascites in broiler chickens

$\checkmark \quad$ Naked-neck birds are more competent homaeo-therms and present superior levels of Hsp70 in the organs first affected by ascites.

$\checkmark$ A combination of ascorbic acid and chromium supplementation can offer a potential protective management practice in preventing the detrimental effects of cold stress in laying hens (SAHIN and SAHIN, 2002).

$\checkmark$ A combination of vitamin C, vitamin E and Zinc can provide protection to the endothelial lining of the lungs and heart, and in turn some protection from onset of ascites.

$\checkmark$ Restricted feeding prevents ascites.

$\checkmark$ During the day time all windows should be kept open and at least two windows at night, depending on local weather conditions, to provide maximum ventilation. Better ventilation prevents ascites.

\section{Conclusions}

Ascites is a multifactorial syndrome like several other metabolic disorders, caused by interactions among environmental, physiological, nutritional and genetic factors. Faster growing chickens have led to farmers enjoying the better phenotypical traits resulting from improved genetic potential. However, the same improved potential could have adverse effects on bird health due to some anatomical and physiological limitations due to the impaired oxygen supply which is unable to sustain the continuous fast growth rate, and this may increase the risk of a higher incidence of ascites syndrome. Selection in fast growth broilers, has also resulted in the development of birds with altered anatomical, physiological, metabolic and haematological parameters, including thyroid hormone activity, partial pressure of $\mathrm{O}_{2}$ and carbon dioxide in venous blood, that coincide with susceptibility to ascites in broiler chickens. These structural or endocrine changes are often linked with ascites susceptibility, and may be influenced during the early stages of development, embryogenesis and incubation. Due to market demand, selection for breast meat yield may impose a greater threat to the bird since chickens with a higher percentage of breast muscle have lower capillary density. Management practices to limit growth rate, such as feed restriction, nutrient density and the form of diet have been applied. These practices indirectly reduce the need for oxygen to partly compensate for the physiological limitations; on the other hand, efforts have been made to normalize red blood cell structure and function, and free radicals scavenged. 
A. Biswas: Pulmonary hypertension syndrome in broiler chickens: a review

\section{Reference}

AHMED, M., A. BISWAS, B. G. ROY, R. B. SRIVASTAVA (2013). Most frequently encountered problems during hatching at cold arid high altitude region like Ladakh in India: Causes and its remedies. World's Poult. Sci. J. 69, 897-902.

DOI: 10.1017 /s0043933913000895.

AREIZA-ROJAS, R. A., P. C. RIVAS LOPEZ, A. HERNANDEZ VASQUEZ (2011). A quantitative study of the pulmonary vascular bed and pulmonary weight: body weight ratio in chickens exposed to relative normoxia and chronic hypobaric hypoxia. Jpn. J. Poult. Sci. 48, 267-274. DOI: $10.2141 /$ jpsa.011030

AUSTIN, E. D., M. T. ROCK, C. A. MOSSE, C. L. VNENCAK-JONES, S. M. YODER, I. M. ROBBINS, J. E. LOYD, B. O. MEYRICK (2010). T- lymphocyte subset abnormalities in the blood and lung in pulmonary arterial hypertension. Respir. Med. 104, 454-462. DOI: 10.1016/j.rmed.2009.10.004

BAGHBANZADEH, A., E. DECUYPERE (2008). Ascites syndrome in broilers: physiological and nutritional perspectives. Avian Pathol. 37, 117-126.

DOI: $10.1080 / 03079450801902062$

BALOG, J. M. (2003). Ascites syndrome (pulmonary hypertension syndrome) in broiler chickens: are we seeing the light at the end of the tunnel? Avian Poult. Biol. Reviews 14, 99-126.

DOI: $10.3184 / 147020603783637490$

BALOG, J. M., B. D. KIDD, N. B. ANTHONY, G. R. HUFF, W. E. HUFF, N. C. RATH (2003). Effect of cold stress on broilers selected for resistance or susceptibility to ascites syndrome. Poult. Sci. 82, 1383-1388.

DOI: $10.1093 / \mathrm{ps} / 82.9 .1383$

BALOG, M. J., N. B. ANTHONY, M. A. COOPER, B. D. KIDD, G. R. HUFF, W. E. HUFF, N. C. RATH (2000). Ascites syndrome and related pathologies in feed restricted broilers raised in a hypobaric chamber. Poult. Sci. 79, 318-323.

DOI: $10.1093 / \mathrm{ps} / 79.3 .318$

BEHROOJ, N., F. KHAJALI, H. HASSANPOUR (2012). Feeding reduced-protein diets to broilers subjected to hypobaric hypoxia is associated with the development of pulmonary hypertension syndrome. Br. Poult. Sci. 53, 658-664.

DOI: $10.1080 / 00071668.2012 .727082$

BISWAS, A., B. G. ROY, D. GOGOI, M. AHMED, S. B. SINGH (2010a). Poultry farming in the cold, arid, Himalayan region of India. World's Poult. Sci. J. 66, 297-307.

DOI: $10.1017 / \mathrm{s} 0043933910000346$

BISWAS, A., V. K. BHARTI, S. ACHARYA, D. D. PAWAR, S. B. SINGH, (2010b). Sea buckthorn: new feed opportunity for poultry in cold arid Ladakh region of India. World's Poult. Sci. J. 66, 707-713.

DOI: $10.1017 / \mathrm{s} 004393391000067 \mathrm{x}$

Vet. arhiv 89 (5), 723-734, 2019 
A. Biswas: Pulmonary hypertension syndrome in broiler chickens: a review

BISWAS, A., M. AHMED, V. K. BHARTI, G. R. BHAGAT, A. KUMAR, R. B. SRIVASTAVA (2011). Growth performance of different chicken breeds at high altitude of Leh ladakh region. Indian J. Poult. Sci. 46, 250-251.

BISWAS, A., V. K. BHARTI, T. RAJ, A. KUMAR, R. B. SRIVASTAVA (2012). Effects of dietary vitamin $\mathrm{E}$ and selenium on growth performance of growing broiler chicken reared at high altitude. Indian J. Poult. Sci. 47, 118-120.

Closter, A. M., P. VAN AS, M. G. ElfERINK, R. P. M. A. CROOIJMANnS, M. A. M. GROENEN, A. L. J. VEREIJKEN, J. A. M. VAN ARENDONK, H. BOVENHUIS. (2012). Genetic correlation between heart ratio and body weight as a function of ascites frequency in broilers split up into sex and health status. Poult. Sci 91, 556-564.

DOI: $10.3382 / \mathrm{ps} .2011-01794$

DECUYPERE, E., J. BUYSE, N. BUYS (2000). Ascites in broiler chickens: exogenous and endogenous structural and functional causal factors. World's Poult. Sci. J. 56, 367-377.

DOI: $10.1079 /$ wps20000025

DECUYPERE, E., M. HASSANZADEH, N. BUYS (2005). Further insights into the susceptibility of broilers to ascites. Vet. J. 169, 319-320.

DOI: 10.1016/j.tvj1.2004.07. 005

DEEB, N., A. SHLOSBERG, A. CAHANER (2002). Genotype-by-environment interaction with broiler genotypes differing in growth rate. 4. Association between responses to heat stress and to cold induced ascites. Poult. Sci. 81, 1454-1462.

DOI: $10.1093 / \mathrm{ps} / 81.10 .1454$

GROVES, P. J. (2002). Environmental determinants of broiler ascites syndrome. Proceedings of the Australian Poult. Sci. Symposium, Sydney, Australia.14, 83-88.

HASSANZADEH, M., J. BUYSE, E. DECUYPERE, (2002). Further evidence for the involvement of cardiac a-adrenergic receptors in right ventricle hypertrophy and ascites in broiler chickens. Avian Pathol. 31, 177-181.

DOI: $10.1080 / 03079450120118676$

IZADINIA, M., M. NOBAKHT, F. KHAJALI, M. FARAJI, F. ZAMANI, D. QUJEQ, I. KARIMI (2010). Pulmonary hypertension and ascites as affected by dietary protein source in broiler chickens reared in cool temperature at high altitudes. Animl. Feed. Sci. Technol. 155, 194-200. DOI: 10.1016/j.anifeedsci.2009.12.009

JULIAN, R. J. (2000). Physiological management and environmental triggers of the ascites syndrome: a review. Avian Pathol. 29, 519-27.

DOI: $10.1080 / 03079450020016751$

JULIAN, R. J. (2007). The response of the heart and pulmonary arteries to hypoxia, pressure, and volume. A short review. Poult. Sci. 86, 1006-1011.

DOI: $10.1093 /$ ps/86.5.1006 
A. Biswas: Pulmonary hypertension syndrome in broiler chickens: a review

MALAN, D. D., C. W. SCHEELE, J. BUYSE, C. KWAKERNAAK, F. K. SIEBRITS, J. D. VAN DER KLIS, E. DECUYPERE (2003). Metabolic rate and its relationship with ascites in chicken genotypes. Br. Poult. Sci. 44, 309-315.

DOI: $10.1080 / 00071660301963$

SAHIN, K., N. SAHIN (2002). Effects of chromium picolinate and ascorbic acid dietary supplementation on nitrogen and mineral excretion of laying hens reared in a low ambient temperature $\left(7^{\circ} \mathrm{C}\right)$. Acta Vet. Brno. $71,183-189$.

DOI: $10.2754 /$ avb200271020183

WIDEMAN, R. F. (2000). Cardio-pulmonary hemodynamics and ascites in broiler chickens. Poult. Avian Biol. Review. 11, 21-43.

WIDEMAN, R. F. (2001). Pathophysiology of heart/lung disorders: pulmonary hypertension syndrome in broiler chickens. World's Poult. Sci. J. 57, 289-307.

DOI: $10.1079 /$ wps20010021

WIDEMAN, R. F., D. D. RHOADS, G. F. ERF, N. B. ANTHONY (2013). Pulmonary arterial hypertension (ascites syndrome) in broilers: A review. Poult. Sci. 92, 64-83.

DOI: $10.3382 / \mathrm{ps} .2012-02745$

WIDEMAN, R. F., O. T. BOWEN, G. F. ERF (2009). Broiler pulmonary hypertensive responses during lipopolysaccharide-induced tolerance and cyclooxygenase inhibition. Poult. Sci. 88, $72-85$.

DOI: $10.3382 /$ ps.2008-00314

XIANG, R. P., W. D. SUN, K. C. ZHANG, J. C. LI, J. Y. WANG, X. L. WANG (2004). Sodium chloride-induced acute and chronic pulmonary hypertension syndrome in broiler chickens. Poult. Sci. 83, 732-736.

DOI: $10.1093 / \mathrm{ps} / 83.5 .732$

ZHOU, D. H., J. WU, S. J. YANG, D. C. CHENG, D. Z. GUO (2008). Intravenous endothelin-1 triggers pulmonary hypertension syndrome (ascites) in broilers. Vet. Med. (Praha). 53, 381391.

DOI: $10.17221 / 1989$-vetmed

ZOER, B., L. KESSELS, A. VEREIJKEN, J. G. R. DE MAY, V. BRUGGENMAN, E. DECUYPERE, C. E. BLANCO, E. VILLAMOR (2009). Effects of prenatal hypoxia on pulmonary vascular reactivity in chickens prone to pulmonary hypertension. J. Physiol. Pharmacol. 60, 119-130. 
A. Biswas: Pulmonary hypertension syndrome in broiler chickens: a review

BISWAS, A.: Sindrom plućne hipertenzije u brojlera: pregledni rad. Vet. arhiv 89, 723-734, 2019.

\section{ABSTRACT}

Nakupljanje tekućine u abdominalnoj šupljini, srčane anomalije, uključujući povećanje srca, meko srce te desna ventrikularna hipertrofija poznati su kao sindrom ascitesa brojlera. Ascites je kao problem uočen najprije na komercijalnim farmama peradi koje su se nalazile na velikim nadmorskim visinama. Četiri su glavna čimbenika nakupljanja tekućine $u$ abdominalnoj šupljini: oštećenje krvnih žila koja utječu na pojačan izlazak tekućine iz kapilara, blokada limfnog sustava što sprečava drenažu limfe, smanjen onkotski tlak u plazmi i povećan vaskularni hidraulički tlak, što može biti uzrokovano razvojem patoloških procesa, uključujući jetrenu, srčanu ili desnu atrioventrikularnu i plućnu hipertenziju. Većina slučajeva ovih metaboličkih bolesti na komercijalnim farmama peradi nastaje zbog plućne hipertenzije. Brojni su uzroci plućne hipertenzije: uzroci iz okoliša (npr. nadmorska visina, stres zbog hladnoće i uvjeta u inkubatoru), tehnopatije, (npr. vrsta hrane, sadržaj hranjivih tvari itd), razvojni uzroci (npr. stopa rasta, zahtjev za kisikom, veličine i zapremnine organa) te krvnih pokazatelja. Svi su ti čimbenici odgovorni za sindrom ascitesa uzrokujući hipoksiju u komercijalno uzgajane peradi. Genetička selekcija mogla bi znatno utjecati na rješavanje problema ascietsa. U prošlosti je genetička selekcija služila za postizanje brzog rasta, visokog prinosa mesa i dobre konverzije hrane. No, mogla je i pogoršati probleme s ascitesom, dok je danas ona najbolje rješenje za uklanjanje ovog metaboličkog poremećaja. S pojavom molekularnogenetičkih istraživanja i razvojem genskih biljega postalo je moguće odrediti genetički temelj ascitesa: genski biljezi mogu se upotrijebiti za uklanjanje sindroma ascitesa u brojlera na modrenim komercijalnim farmama.

Ključne riječi: metabolički poremećaj; plućna hipertenzija; ascites; genetička selekcija; brojler 